DOI: https://doi.org/10.47405/mjssh.v6i4.767

\begin{tabular}{|c|c|}
\hline 4 & Malaysian Journal of Social Sciences and Humanities (MJSSH) \\
\hline $\begin{array}{l}\text { Malaysian Journa of } \\
\text { Social cciences and }\end{array}$ & Volume 6, Issue 4, April 2021 \\
\hline (MJ-sSH) & e-ISSN : 2504-8562 \\
\hline & $\begin{array}{l}\text { Journal home page: } \\
\text { www.msocialsciences.com }\end{array}$ \\
\hline
\end{tabular}

\title{
Integrating Facebook as a Platform of Discussion Among ESL Learners in International School
}

Belvinna Kaur Ajaib Singh¹, Azlina Abdul Aziz' ${ }^{1}$

1 Faculty of Education, Universiti Kebangsaan Malaysia (UKM)

Correspondence: Belvinna Kaur Ajaib Singh (vinnakaur@gmail.com)

\begin{abstract}
This paper presents a systematic literature review of relevant published studies on integrating Facebook as a platform of discussion in the ESL classroom. The published studies are taken from the year of 2011 to 2019. The systematic literature review gives an overview about the positive impact of using Facebook as a platform of discussion for the ESL learners and the benefits of applying multimodality in teaching the ESL learners. The paper also investigates the challenges faced in integrating Facebook into the teaching and learning. The results of most published papers indicate that learners and educators are comfortable with the presence of Facebook as a platform of discussion and provides a positive feedback for the future ESL learners and educators to implement Facebook. The past studies indicate that Facebook plays a role in motivating the learners and promotes blended learning in improving the learner's English language skills. The past studies also specify the challenges faced by both learners and educators in using Facebook. The limitations of past related studies and future directions for research were being further discussed.
\end{abstract}

Keywords: Facebook, ESL learners, multimodality, discussion

\section{Introduction}

Technology has brought a vast change in communication among people. The spread of technology has given a change in the life of people in their daily lives. Humans are very much doing everything with their smart phones nowadays. Moreover, technology has brought a change in the education system as well. People can now use technology in supporting learning apart from doing online business and making new friends. With the help of technology, learning can now take place anywhere and anytime. This has eased many people and now learning is much easier. With the right tool, students can now enjoy learning in a fun and exciting way. The students can also share their thoughts and ideas with new people that they meet through technology. Through the help of technology teachers can now conduct lessons in manners that could have not been possible before.

In addition, social media is known to be the varsity of the new generation for teaching and learning purposes. Globally, the world has adapted to the usage of technology in teaching and learning in schools. However, we are yet to explore the usage of social media in the classroom learning and teaching process. This social media could replace the old chalk and talk sessions and give students a new phase of learning as they can infuse new methods and sessions of presentations. The social media would play a significant role in changing the learners learning styles and create the utmost respect for the subjects being carried out. For ESL learners, they come from a non-English speaking background, 
hence the activities for them should be student-centered learning. Learning English can be difficult for ESL students as their command of English is not strong and they tend to get boring or demotivated with common chalk and talk sessions or power point slides. Aleksander (2015) mentioned that the use of social media and technology improved the learners' capabilities to learn and perform. Che Wan (2018) also mentioned that technology supports a successful design for the learning process. The social media would break their nervousness and they would be able to explain their ideas without the fear of being judged or suppressed by other learners.

Learners are bound to their personality traits and they have different attitudes and acceptance towards voicing out in the classroom. Most learners prefer to remain silent in the classroom as they are afraid of making mistakes and being taunted for the words or their English proficiency level. However, when these learners are provided with opportunities to learn offline and have a discussion on social medias such as Facebook, they are more active and willing to share their ideas or thoughts. Voyce (2017) mentioned that social media such as Facebook can help students to share and obtain materials. Moreover, they can also assist each other to complete assignments and classroom assignments. Voyce (2017) also mentioned that discussion that took place online has increased the participation rate of learners compared to classroom learning. This could ease the learning process and give confidence to the students to voice out their opinions without having the fear of being judged. Learners look for opportunities to have discussions online as they can fill in the gap during the classroom hours and expand their ideas. Facebook allows learners to explore the similarities and differences of ideas among different learners to show collaborative learning. It is not just a platform to share ideas, but it can be a platform to exchange knowledge without having the fear of being judged.

However, technology does have its own side effects and both educators and learners are exposed to challenges when dealing with technology. Low (2016) mentioned that educators that has higher number of students uses the Facebook to enhance communication skills. However, there are learners that belongs to the low-income category and they do not have the internet access. Nadia (2016) mentioned that when educators introduced Facebook as a platform of discussion in a university in Kuala Lumpur, the respond received was higher compared to a university in Bangladesh. Learners that belongs to the low-income or middle-income community failed to show up in the online discussion as there are not given the tools and has difficulties in accessing the internet. Faryadi (2017) said in his research that a larger group of students are also difficult to control when it comes to online learning. Faryadi (2017) said the educators need to monitor the learners closely to ensure that they are focusing on the Facebook discussion instead of using other websites during the teaching and learning process. However, the process is much effective when the educators are giving the learners time to complete the discussion at their respective homes. Certain learning institutions will also face problems with technology aid as the desktops are insufficient.

\section{Research Objectives and Research Questions}

The main objective of the systematic review is to show a synthesis of empirical evidence found in the past related studies on the integration of Facebook in the ESL teaching and learning so that further intervention development and research in this area can be carried out. This study is carried out to answer three research questions:

i. What are the positive impacts of using Facebook as a platform of discussion for ESL learners?

ii. What are the benefits of applying multimodality in teaching ESL learners?

iii. What are the challenges faced by ESL learners when using Facebook as a platform of discussion?

\section{Literature Review}

\section{Definition of Facebook}


Facebook or more commonly known as FB is a platform of social media that allows people from all over the world to keep in touch and make new friends. This social media also allows people to share pictures, thoughts and ideas as well as making open discussions. Recently, Facebook has been a place for educators to carry out discussions through online learning method. Facebook is user friendly and users can download the application to their phones, desktops or laptops for daily usage. Many educators have tried to integrate learning through this application and received positive feedback. Anyone is entitled for using Facebook as long as they adhere to all the rules and regulations.

The use of FB into ESL classroom is considered new as this is an informal way for educators to conduct lessons with the learners. The FB integration into ESL classroom emphasizes on new methods to keep the learners active and replacing the old chalk and talk method. Using FB in the classroom can also allow students to expand their knowledge has they share their existing ideas to other learners. FB is a tool that would allow students to collaborate with learners throughout the world. This can allow learners to gain more self-confidence by sharing their ideas and thought. Moreover, FB would also benefit the learners as they can explore all the possibilities of teaching with this tool. The attractive nature of this tool would motivate both learners and educators to improve in their English skills as FB has a lot of methods to offer.

\section{Technology}

Gumpurt and Chun (1999) mentioned that technology plays an important role in the teaching and learning process. Technology influences the product and the extension of learning process. Moreover, Amin (2016) mentioned that technology helps learners to communicate with their friends and family and allow them to communicate with native speakers to improve their speaking capabilities. In his research, Amin (2016) mentioned that technology has improved the language learning familiarity. The learners believe that the technology has helped them to expand their learning capabilities and allowed them to learn in a fun and positive manner. Alm (2006) also mentioned that various technology has been employed in the area of education. The technology creates a new atmosphere for both educators and learners to apply in the teaching and learning process. In the recent years, educators have seen a large change in the learning system through the help of technology. The technology has modified the traditional teacher-centered method to a fun and more challenging method. Since technology is easily accessible, anyone can use it at any time therefore, it is easier for learners as they can utilize this opportunity to learn and improvise.

\section{Blended Learnings Scaffold to Online Learning}

The online learning has created a platform for educators to carry out their lessons in different and innovative method. Abdul Hammed Abdul Majid (2015) researched about the potential of blended scaffolding strategies through Facebook. He mentioned in his research that learners that used Facebook in their learning improved their writing skills in English. By using blended learning, students would be more eager and excited to learn and contribute their ideas in the classroom. According to Siti Hamin Stapa (2015) Facebook has improved the learner's communication skills. The learners are actively participating in classroom discussions and Facebook has increased their confidence level. Facebook is a platform where the students would be sharing their ideas and thoughts with different learners and strangers as well. When the learners are not criticized, they feel they are not being judged for their thoughts.

Facebook would boost the learner's confidence level as it is a big platform for the learners to voice out their opinion without having the fear of being adjudicated. It will also allow them to post and comment on another learners' post. In which, everyone would benefit from.

\section{Integrating Creativity and Technology}

Being in the $21^{\text {st }}$ century, educators are always looking for new pedagogy to conduct lessons in the classroom. As technology is easily accessible and affordable over time, educators can integrate this 
technology into classroom learning. This is supported by Mishra (2016) where researcher mentioned that technology is a new approach for pedagogical purposes. Creativity is vital in learning process and infusing creativity with technology available would create a fun and enjoyable lesson. Moreover, the $21^{\text {st }}$ century learning is more towards real-life situation, therefore learning can take place anywhere. Technology is known to be man's companion now therefore; a learner can explore all the educational sites within splits of seconds. Integrating creativity and technology with create a new vibe into the institution because learners would feel keen towards classroom learnings and projects (Henriksen, 2016).

\section{Social Networking Sites as Learning Tools}

One of the social networking sites that belongs to the Web 2.0 Technology is Facebook. Facebook is a social networking site used to connect people around the world. This site can be used by learners to interact with other learners around the world and this can improve their communication and writing skills. Siti (2016) also mentioned in her research that Facebook is well adapted by learners. The learners prefer to use Facebook as a tool to exchange ideas and improve their writing skills.

\section{The Advantages and Disadvantages of Using Facebook in Classroom Learning}

Social media enhances peer communication and increases learner's confidence. However, using social media in a classroom context is considered informal learning. Learners are often distracted by other social networking sites, therefore keeping their attention for long on Facebook can be an issue. According to Voyce (2017), educators need to ensure learners are not distracted by other networking sites. Educators would also need to ensure that the learning on Facebook is in correct proportion of time. If the learners are given too much of time, they would feel bored or even loose interest. Educators needs to decide what is the suitable time for students to be on Facebook for learning purposes.

However, Facebook has also proven to be useful for learners. Shaidatul (2017) mentioned that Facebook is a positive site to improve learners' capabilities of learning. Most educators have seen a positive impact on their learners with the help of Facebook. She also mentioned that educators should guide and watch over learners when they are using Facebook to learn.

\section{Facebook As an Alternative to A Real-Life Classroom}

The objective of Facebook is to create a communication despite the location of the user. This has been a plus point for educators to motivate the learners to voice out their opinion when necessary or when needed. Some educators are very shy, and they do not make any communication in the classroom, therefore, the educator is often challenged to know their understanding towards the subject. Maskell (2015) mentioned that learners are given the option to answer the discussion based on their pace of time and space. This has significantly changed the learner's opinion on participating in the discussion. Yunus (2012) also stated that learners are fond by Facebook and they prefer to answer the discussions through Facebook. Through his research, he added that educators should include Facebook as a pedagogical method of teaching and learning has more learners are impressed with the idea of using Facebook in their learning process.

\section{Method}

The procedure involved in conducting the systematic literature review was planning the review. The topic was selected, and researcher search out for relevant topics that would fit the research. Most significant researches were chosen to ensure the data received is valid and can be used in developing further researches. Next, I looked for data to identify and review the relevant researches that explored the integration of Facebook as a platform of discussion for the ESL teaching and learning classroom. The final stage of the systematic review was to report the review through communicating the results. 
To receive quality papers, the following international bibliographic databases namely Google Scholar, Scopus, Tun Sri Lanang resources, Scribd were used to identify the relevant researches. I used papers that were published in English from the year of 2012 to 2019 to collect the data. The combination of terms used to search for the past related studies in the keywords field of the above databases were "Facebook in teaching and learning", "Facebook in ESL classroom". "Facebook as a platform of discussion", "Online Pedagogical Method", and "Blended learning". These keywords helped to achieve data that were most relevant to the topic. Based on the results, the abstract was then screened as the following criteria:

1. The group of participants should belong to the ESL classroom.

2. The studies should be conducted in teaching English as a second language (ESL) context.

3. The studies should focus on the integration of Facebook as a platform of discussion.

4. English language should be used as a medium of writing in the paper.

5. The studies could employ qualitative, quantitative or mixed-method research design as more methodologically rigorous studies are needed.

However, it was tough to include all the findings on the available databases. Therefore, only 14 past researches were chosen to write the report.

\section{Result and Discussion}

As per mentioned 14 past researches were chosen to complete the past paper. Five best researches were chosen to produce a systematic literature review table to provide a better understanding on the topic given. The empirical evidence to support the integration of Facebook as a platform of multimodal to ESL teaching and learning are as summarized in the table as follows.

Table 1: Systematic literature review year 2010-1019

\begin{tabular}{|c|c|c|c|c|c|}
\hline & Article 1 & Article 2 & Article 3 & Article 4 & Article 5 \\
\hline $\begin{array}{l}\text { Writer's } \\
\text { name } \\
\text { Year of } \\
\text { Publicatio } \\
\mathrm{n} \\
\text { Title } \\
\text { Name of } \\
\text { Journal } \\
\text { Page } \\
\text { Publisher, }\end{array}$ & $\begin{array}{l}\text { Elda } \\
\text { Tartari, } \\
\text { July } 2015 . \\
\text { The Use } \\
\text { of Social } \\
\text { Media for } \\
\text { Academic } \\
\text { Purposes } \\
\text { in Student } \\
\text { Learning } \\
\text { Process. } \\
\text { Academic } \\
\text { Journal of } \\
\text { Interdiscip } \\
\text { linary } \\
\text { Studies. } \\
\text { MCSER } \\
\text { Publishing } \\
\text { Rome- } \\
\text { Italy. Pp } \\
\text { 393-398. }\end{array}$ & $\begin{array}{l}\text { Noraien } \\
\text { Mansor, Suria } \\
\text { Hani Ibrahim, } \\
\text { Nina Marlini } \\
\text { Ahmad, Wan } \\
\text { Nurhafeza } \\
\text { Wan Salam, } \\
\text { Mohd } \\
\text { Zulkarnain, } \\
\text { Husna Nurul } \\
\text { Izzah } \\
\text { Jamaluddin. } \\
\text { March 2014. } \\
\text { Social Media } \\
\text { in ESL } \\
\text { Classroom : } \\
\text { Exploring The } \\
\text { Impact on } \\
\text { Language } \\
\text { Learning. } \\
\text { Journal of } \\
\text { Business and } \\
\text { Social } \\
\text { Development. } \\
\text { Pp 14-18. }\end{array}$ & $\begin{array}{l}\text { Noraien } \\
\text { Mansor. } \\
\text { October } \\
2016 . \\
\text { Enhancing } \\
\text { Communicati } \\
\text { on Via Social } \\
\text { Media in } \\
\text { ESL } \\
\text { Classroom. } \\
6^{\text {th }} \\
\text { International } \\
\text { Conference } \\
\text { on Language } \\
\text {, Education } \\
\text { and } \\
\text { Innovation. } \\
\text { Pp 140-145. }\end{array}$ & $\begin{array}{l}\text { Voyce Li. } \\
\text { June } 2017 . \\
\text { Social Media } \\
\text { in English } \\
\text { Language } \\
\text { Teaching and } \\
\text { Learning. } \\
\text { International } \\
\text { Journal of } \\
\text { Learning and } \\
\text { Teaching } \\
\text { Vol. 3, No. } \\
\text { 2. Pp 148- } \\
\text { 153. }\end{array}$ & $\begin{array}{l}\text { Amin Ali Al } \\
\text { Mubarak. } \\
\text { December } 2016 . \\
\text { Learning English } \\
\text { as a Second } \\
\text { Language through } \\
\text { Social Media : } \\
\text { Saudi Arabian } \\
\text { Tertiary Context. } \\
\text { International } \\
\text { Journal of } \\
\text { Linguistics. Pp } \\
\text { 112- 127. }\end{array}$ \\
\hline
\end{tabular}


DOI: https://doi.org/10.47405/mjssh.v6i4.767

\begin{tabular}{|c|c|c|c|c|c|}
\hline & Article 1 & Article 2 & Article 3 & Article 4 & Article 5 \\
\hline $\begin{array}{l}\text { Purpose of } \\
\text { the study }\end{array}$ & $\begin{array}{l}\text { The } \\
\text { purpose of } \\
\text { this study } \\
\text { is to } \\
\text { investigate } \\
\text { the attitude } \\
\text { toward the } \\
\text { use of } \\
\text { social } \\
\text { media in } \\
\text { learning } \\
\text { process. }\end{array}$ & $\begin{array}{l}\text { The purpose of } \\
\text { the study is to } \\
\text { explore the use } \\
\text { of Facebook in } \\
\text { ESL classroom } \\
\text { and also the } \\
\text { perceptions of } \\
\text { students } \\
\text { towards the } \\
\text { implementatio } \\
n \text { of social } \\
\text { media in } \\
\text { language } \\
\text { learning. }\end{array}$ & $\begin{array}{l}\text { This study is } \\
\text { focused on } \\
\text { students } \\
\text { perceptions } \\
\text { on the } \\
\text { implementati } \\
\text { ons of social } \\
\text { media in } \\
\text { ESL } \\
\text { Classrooms } \\
\text { to enhance } \\
\text { their } \\
\text { communicati } \\
\text { on skills. }\end{array}$ & $\begin{array}{l}\text { The purpose } \\
\text { of the study } \\
\text { is to show } \\
\text { the use of } \\
\text { social media } \\
\text { for English } \\
\text { learning and } \\
\text { the } \\
\text { relationship } \\
\text { between six } \\
\text { possible } \\
\text { frequent } \\
\text { learning } \\
\text { activities } \\
\text { through } \\
\text { social media. }\end{array}$ & $\begin{array}{l}\text { The purpose of the } \\
\text { study is to show } \\
\text { the incorporation } \\
\text { of social media in } \\
\text { learning English } \\
\text { among tertiary } \\
\text { level students. }\end{array}$ \\
\hline $\begin{array}{l}\text { Research } \\
\text { Objectives } \\
\text { and } \\
\text { Questions }\end{array}$ & $\begin{array}{l}\text { The } \\
\text { objective } \\
\text { is to } \\
\text { investigate } \\
\text { do } \\
\text { students } \\
\text { use social } \\
\text { networkin } \\
\text { g sites as } \\
\text { study } \\
\text { source, to } \\
\text { investigate } \\
\text { does } \\
\text { students } \\
\text { improve } \\
\text { foreign } \\
\text { language } \\
\text { skills on } \\
\text { social } \\
\text { networkin } \\
\text { g sites and } \\
\text { to study } \\
\text { students } \\
\text { attitude } \\
\text { towards } \\
\text { the use of } \\
\text { social } \\
\text { media in } \\
\text { academic } \\
\text { purposes. }\end{array}$ & $\begin{array}{l}\text { The objective } \\
\text { of the research } \\
\text { is to find out } \\
\text { if Facebook is } \\
\text { an effective } \\
\text { tool for } \\
\text { students } \\
\text { interaction in } \\
\text { their } \\
\text { discussions } \\
\text { purposes. This } \\
\text { study is also to } \\
\text { understand } \\
\text { students } \\
\text { perception } \\
\text { towards } \\
\text { implementing } \\
\text { social media in } \\
\text { ESL } \\
\text { Classroom for } \\
\text { learning } \\
\text { purposes. }\end{array}$ & $\begin{array}{l}\text { The } \\
\text { objective of } \\
\text { the study is } \\
\text { to understand } \\
\text { the students } \\
\text { perceptions } \\
\text { on } \\
\text { implementin } \\
\text { g social } \\
\text { media in } \\
\text { ESL } \\
\text { Classroom. } \\
\text { The study } \\
\text { also looks } \\
\text { into social } \\
\text { media has a } \\
\text { tool for } \\
\text { enhancing } \\
\text { effective } \\
\text { communicati } \\
\text { ons skills. } \\
\text { The study } \\
\text { also studies } \\
\text { the impact of } \\
\text { social media } \\
\text { on } \\
\text { encouraging } \\
\text { students to } \\
\text { participate in } \\
\text { existing } \\
\text { technology. }\end{array}$ & $\begin{array}{l}\text { The } \\
\text { objective of } \\
\text { the study is } \\
\text { to understand } \\
\text { how often } \\
\text { students use } \\
\text { social media } \\
\text { for English } \\
\text { lessons. It } \\
\text { also studies } \\
\text { on how often } \\
\text { students use } \\
\text { their social } \\
\text { media for } \\
\text { education } \\
\text { and non } \\
\text { educational } \\
\text { activities. }\end{array}$ & $\begin{array}{l}\text { The research } \\
\text { objective is to } \\
\text { explore the } \\
\text { benefits of using } \\
\text { social media as a } \\
\text { tool in learning } \\
\text { English among } \\
\text { undergraduate } \\
\text { students. To } \\
\text { explore the } \\
\text { potential benefits } \\
\text { and threats of } \\
\text { using social media. }\end{array}$ \\
\hline $\begin{array}{l}\text { Literature } \\
\text { Review }\end{array}$ & $\begin{array}{l}\text { For many } \\
\text { years, } \\
\text { researcher } \\
\text { s have } \\
\text { found that } \\
\text { networked } \\
\text { computers }\end{array}$ & $\begin{array}{l}\text { The } \\
\text { education } \\
\text { system of a } \\
\text { acountry } \\
\text { plays a } \\
\text { crucial role } \\
\text { in forming }\end{array}$ & $\begin{array}{l}\text { Students are } \\
\text { encouraged to } \\
\text { use social } \\
\text { medias such as } \\
\text { Facebook to } \\
\text { improve in } \\
\text { their language }\end{array}$ & $\begin{array}{l}\text { Social media } \\
\text { is an } \\
\text { essential tool } \\
\text { in learning } \\
\text { nowadays. } \\
\text { The social } \\
\text { media }\end{array}$ & $\begin{array}{l}\text { Using social media } \\
\text { in the formal } \\
\text { education system is } \\
\text { new and not } \\
\text { many educators } \\
\text { and learners are } \\
\text { aware of this }\end{array}$ \\
\hline
\end{tabular}


DOI: https://doi.org/10.47405/mjssh.v6i4.767

\begin{tabular}{|c|c|c|c|c|}
\hline Article 1 & Article 2 & Article 3 & Article 4 & Article 5 \\
\hline $\begin{array}{l}\text { offers a } \\
\text { competitiv } \\
\text { e learning } \\
\text { environme } \\
\text { nt. } \\
\text { M.Fiori ( } \\
\text { 2009) } \\
\text { stated that } \\
\text { Facebook } \\
\text { is a tool } \\
\text { that } \\
\text { supplies } \\
\text { learning } \\
\text { activities } \\
\text { where } \\
\text { students } \\
\text { can } \\
\text { interact } \\
\text { and } \\
\text { communic } \\
\text { ate with } \\
\text { native } \\
\text { speakers. } \\
\text { Bakar } \\
\text { (2009) } \\
\text { mentioned } \\
\text { that e- } \\
\text { learning is } \\
\text { an } \\
\text { evolution } \\
\text { in the } \\
\text { English } \\
\text { language } \\
\text { learning. } \\
\text { He also } \\
\text { mentioned } \\
\text { that } \\
\text { students } \\
\text { that uses } \\
\text { Facebook } \\
\text { in their } \\
\text { daily life } \\
\text { have } \\
\text { shown } \\
\text { better } \\
\text { performan } \\
\text { ce in their } \\
\text { reading } \\
\text { and } \\
\text { writing } \\
\text { skills. The } \\
\text { social } \\
\text { media also } \\
\text { allow them }\end{array}$ & $\begin{array}{l}\text { the nation. } \\
\text { Therefore, } \\
\text { complying } \\
\text { with the } \\
\text { newest } \\
\text { education } \\
\text { policy, the } \\
\text { Ministry of } \\
\text { Education in } \\
\text { Malaysia has } \\
\text { stated the } \\
\text { important of } \\
\text { ICT in the } \\
\text { learning } \\
\text { process. } \\
\text { Students in } \\
\text { Malaysia re } \\
\text { introduced to } \\
\text { various } \\
\text { forms of } \\
\text { effective } \\
\text { social media } \\
\text { learning. } \\
\text { Bosch (2019) } \\
\text { mentioned } \\
\text { that } \\
\text { Facebook is } \\
\text { being } \\
\text { recognized } \\
\text { as a } \\
\text { reputable e- } \\
\text { learning } \\
\text { platform. } \\
\text { However, } \\
\text { Madge } \\
\text { (2009) } \\
\text { mentioned } \\
\text { that } \\
\text { Facebook is } \\
\text { not a formal } \\
\text { teaching tool } \\
\text { therefore the } \\
\text { former } \\
\text { classroom } \\
\text { teaching is } \\
\text { till vital. } \\
\text { Selwyn } \\
\text { (2007 ) on } \\
\text { the other } \\
\text { hand } \\
\text { mentioned } \\
\text { that } \\
\text { Facebook } \\
\text { reflects a }\end{array}$ & $\begin{array}{l}\text { communicatio } \\
\mathrm{n} \text { skills. A lot } \\
\text { of students } \\
\text { nowadays has } \\
\text { an easy access } \\
\text { to social media } \\
\text { account. } \\
\text { Students can } \\
\text { use this } \\
\text { platform to } \\
\text { voice out their } \\
\text { opinions } \\
\text { without having } \\
\text { the fear of } \\
\text { being judged. } \\
\text { Kabilan et al. } \\
\text { (2010) } \\
\text { mentioned in } \\
\text { their findings } \\
\text { that students } \\
\text { confidence and } \\
\text { motivation to } \\
\text { improve in } \\
\text { English } \\
\text { learning has } \\
\text { improved } \\
\text { tremendously. } \\
\text { Not only } \\
\text { Facebook, } \\
\text { students can } \\
\text { also use their } \\
\text { Instagram } \\
\text { account to } \\
\text { enhance } \\
\text { communicatio } \\
\text { n skills. } \\
\text { Salomon } \\
\text { (2013 ) and } \\
\text { Bell ( } 2013 \text { ) } \\
\text { both agrees } \\
\text { that Instagram } \\
\text { has allowed } \\
\text { students to } \\
\text { have } \\
\text { confidence in } \\
\text { expressing } \\
\text { their ideas } \\
\text { virtually. This } \\
\text { would allow } \\
\text { students to } \\
\text { learn from a } \\
\text { different } \\
\text { method instead } \\
\text { of the old }\end{array}$ & $\begin{array}{l}\text { accounts } \\
\text { such as } \\
\text { Facebook, } \\
\text { Youtubes, } \\
\text { Instagram } \\
\text { are essential } \\
\text { part of } \\
\text { learning. } \\
\text { Voyce ( } 2017 \\
\text { ) mentioned } \\
\text { that students } \\
\text { shows a } \\
\text { tremendous } \\
\text { improvement } \\
\text { after using } \\
\text { Youtube } \\
\text { videos in } \\
\text { enhancing } \\
\text { their } \\
\text { language } \\
\text { skills. } \\
\text { Teachers can } \\
\text { also use } \\
\text { various } \\
\text { platforms of } \\
\text { social media } \\
\text { to create a } \\
\text { conducive } \\
\text { learning } \\
\text { environment. } \\
\text { Voyce } \\
\text { (2017) also } \\
\text { mentioned } \\
\text { that the use } \\
\text { of social } \\
\text { media has } \\
\text { increased } \\
\text { students } \\
\text { performances } \\
\text { in } \\
\text { completing } \\
\text { the task on } \\
\text { time. } \\
\text { Students can } \\
\text { share their } \\
\text { learning } \\
\text { activities, } \\
\text { materials and } \\
\text { other related } \\
\text { findings } \\
\text { about the } \\
\text { task assign } \\
\text { by teacher. } \\
\text { Students also }\end{array}$ & $\begin{array}{l}\text { technology and the } \\
\text { impacts. Social } \\
\text { networking such as } \\
\text { Facebook, } \\
\text { YouTube, video } \\
\text { stream and other } \\
\text { social medias has } \\
\text { shown a vast } \\
\text { cooperation with } \\
\text { English learning. } \\
\text { Social media } \\
\text { allows students to } \\
\text { share relevant } \\
\text { information and } \\
\text { improve in their } \\
\text { language skills. } \\
\text { Gumpurt \& Chun ( } \\
\text { 1999 / mentioned } \\
\text { that technology } \\
\text { plays a vital role in } \\
\text { forming the } \\
\text { learning process. } \\
\text { There are different } \\
\text { types of social } \\
\text { media that exists } \\
\text { and learners can } \\
\text { choose relevant } \\
\text { social media that } \\
\text { they wished to } \\
\text { apply in their } \\
\text { learning process. } \\
\text { Social medias such } \\
\text { as Facebook, } \\
\text { Blogs, Twitter has } \\
\text { proved that this } \\
\text { platform can help } \\
\text { students to increase } \\
\text { their motivation } \\
\text { and determination } \\
\text { to improve in } \\
\text { English. These } \\
\text { effective tools are } \\
\text { now openly used in } \\
\text { many education } \\
\text { centers. Chen ( } \\
\text { 2013 ) in his study } \\
\text { found that social } \\
\text { media is being } \\
\text { invested in many } \\
\text { forms of education. } \\
\text { Writers are enable } \\
\text { to express their } \\
\text { points of view and } \\
\text { they gain more }\end{array}$ \\
\hline
\end{tabular}


DOI: https://doi.org/10.47405/mjssh.v6i4.767

\begin{tabular}{|c|c|c|c|c|}
\hline Article 1 & Article 2 & Article 3 & Article 4 & Article 5 \\
\hline $\begin{array}{l}\text { to } \\
\text { represent } \\
\text { themselves } \\
\text { and keep } \\
\text { their social } \\
\text { presence } \\
\text { with other } \\
\text { members ( } \\
\text { Guaman, } \\
\text { 2012). } \\
\text { Social } \\
\text { media } \\
\text { works as a } \\
\text { pedagogy } \\
\text { to help } \\
\text { students in } \\
\text { increasing } \\
\text { their } \\
\text { learning } \\
\text { capabilitie } \\
\text { s. } \\
\text { Quantitati } \\
\text { ve } \\
\text { research. }\end{array}$ & $\begin{array}{l}\text { strong role in } \\
\text { students } \\
\text { language } \\
\text { learning. } \\
\text { Facebook is } \\
\text { a social } \\
\text { media } \\
\text { whereby } \\
\text { students can } \\
\text { appreciate } \\
\text { the work of } \\
\text { their friends } \\
\text { and gain } \\
\text { more } \\
\text { knowledge. } \\
\text { Qualitative } \\
\text { research }\end{array}$ & $\begin{array}{l}\text { chalk and talk } \\
\text { method and } \\
\text { increase their } \\
\text { potentials to } \\
\text { learn English. } \\
\text { Hew (2011) } \\
\text { mentioned that } \\
\text { using } \\
\text { Facebook } \\
\text { would be a } \\
\text { new pedagogy } \\
\text { and would } \\
\text { allow teachers } \\
\text { to create a } \\
\text { different } \\
\text { learning } \\
\text { environment } \\
\text { for the } \\
\text { students. } \\
\text { Qualitative } \\
\text { research }\end{array}$ & $\begin{array}{l}\text { become more } \\
\text { goal oriented } \\
\text { through } \\
\text { social media } \\
\text { because they } \\
\text { are capable } \\
\text { of finding a } \\
\text { lot of } \\
\text { information } \\
\text { regarding } \\
\text { their English } \\
\text { assignments. } \\
\text { Quantitative } \\
\text { research. }\end{array}$ & $\begin{array}{l}\text { ideas after posting } \\
\text { their opinions. } \\
\text { Gonzalez ( 2012) } \\
\text { in his study } \\
\text { mentioned that } \\
\text { social media } \\
\text { applications are } \\
\text { helpful in } \\
\text { educational } \\
\text { settings. The } \\
\text { social media which } \\
\text { is easily accessed } \\
\text { can allow students } \\
\text { to communicate } \\
\text { with students from } \\
\text { other region. } \\
\text { Therefore, the } \\
\text { sharing of } \\
\text { knowledge is more } \\
\text { broader compared } \\
\text { to classroom } \\
\text { setting. } \\
\text { Quantitative } \\
\text { research }\end{array}$ \\
\hline
\end{tabular}

\section{Discussion}

These past researches have studied the integration of Facebook in the teaching and learning of ESL classroom. Undeniably, Facebook has shown importance in the teaching and learning process. Most learners and educators are comfortable of using Facebook as a platform of discussion and communication. Nevertheless, the involvement of technology in the ESL classroom signifies the literacy of the learners towards teaching and learning process in the classroom. The researches have shown that Facebook has positive side effects as well as the negative effects. All of this comes under circumstances of a new pedagogical method and can be overcome throughout the years. Amin (2016) mentioned that the involvement of Facebook in the ESL classroom has a new perspective of teaching. Moreover, the educators feel anticipated to integrate technology as this could change the dimension of teaching and learning process.

\section{Positive Effects of using Facebook as a Platform of Discussion for ESL Learners}

When new methods are introduced in the traditional classroom, the learners are very excited as they get to experiment with the tools. This is a healthy situation as our learners needs to be fed with the newest information to ensure the quality of teaching and learning status. In the $21^{\text {st }}$ century, learners are often looking for opportunities that would fit in the global market. It can be secondary or tertiary education; the learners are often seen comparing themselves and the teaching methods used by the teachers. ESL learners often struggles to compete with native speakers as their main language is their mother tongue such as Chinese, Malay or Tamil in Malaysia. This has seen to affect the learner's motivation level to speak out in the classroom or to voice out their opinion. The ESL learners often struggles to communicate with their peers or educators. The involvement of Facebook has changed the dimension of learner's communication skills. 


\section{Increase in Motivation}

Facebook has often seen to change the learner's perception of communicating. There are learners that are afraid to talk in the classroom as they are afraid, they might make mistakes in pronouncing some words and their friends would look down on them. However, as a medium of communication Facebook is seen as a place for these learners to share their thoughts and views. Philips (2010) mentioned that this platform has been very useful for learners that belongs to the ESL category. Khaled (2016) mentioned in his research that his tertiary level learners felt comfortable expressing their points via Facebook and within weeks he could see positive involvement in the classroom discussion. Nonetheless, this give the learners a space of comfort and they are more than willing to learn and conquer a new language. These sort of opportunities changes their thinking and willingness to learn (Ghalib, 2014). When given the right space, the learners are capable pf achieving positive results.

\section{Increases Multimodality in Learners}

When the learners can explore their options on learning, they become a global need. Most countries these days, wants learners that are capable of learning from different platforms apart from the traditional classrooms. Tertiary education mostly focuses on online learning so that distance learning can take place and learners can explore their choices on enrolling themselves in a prestigious university. Facebook would be a great platform for them to express such opinions which can be shared globally, and learners get to learn more and gain more knowledge. These are opportunities for learners to also make friends with learners throughout the world. Given the option of learning, these learners should be exposed to platforms tat would allow them to perform better.

\section{Challenges Faced by Learners in using Facebook}

The online learning options seems fair, however, there are challenges to be faced when implementing the technology in teaching and learning. There are learners with different groups of household earnings. To enable a learner to use the Facebook, he or she needs to have a good internet connection and a gadget. The institutions do not provide the learners with gadgets to perform online learning at home. Therefore, when integrating Facebook as an option, the educator needs to consider the challenges that comes through. Romualdo (2017) mentioned in his research regarding learners responds towards the integration of Facebook. Learners complained that due to weak internet connection, they often failed to complete the submission and they would delay the process of answering the discussion questions.

Low and Warawudhi (2016) mentioned that learners are often distracted by the notifications that comes on their Facebook screen. Learners mentioned that they have short attention span when it comes to using Facebook as a platform to learn or to discuss about a topic. They are often triggered to check their messages or other social media accounts. Some student even mentioned that they usually copy paste answers from the websites to post in the discussion (Low \& Warawudhi, 2016). These be an unhealthy environment ad it could demotivate other learners to perform better.

In previous researches, it is also mentioned that learners have issues in getting a proper internet connection as they often struggle to get a stable connection. These can be seen as a huge challenge for learners that lives in a rural area. These learners are often left behind in discussions and as time passes, their motivation to answer the questions would be low.

In conclusion, educators and learners are both interested and keen in using Facebook as a platform of discussion. However, there are certain circumstances that could be a problem. Nevertheless, if given proper tools, the ESL learners are capable of achieving a good skill in using Facebook as a platform to discuss about educational issues. 


\section{Limitations and Recommendations for Future Research and Practice}

The results shown in the systematic literature review are based on the criteria chosen by the previous researcher. The first limitation would be criteria. As the main aim of the systematic literature review is to gain past research on Facebook as a platform of discussion for ESL learners, the results are not holistic based. The researchers have carried out research based on their institutions and their level of learners.

It is reported and elaborated in the shortlisted studies that majority of the respondents believed that Facebook is a good and effective platform to voice out their opinions and post discussions. However, further discussion is needed on how educators can overcome the challenges faced by learners to integrate Facebook in the ESL teaching and learning. It is hoped that this systematic review will provide empirical evidence for both educators and learners of ESL classroom in integrating Facebook as a multimodal platform of discussion.

\section{References}

Aamirah Aiza Zakaria, Lee Yan Di, Melor Md Yunus. (2017). 21st century education in teaching English as a second language (Esl) in Malaysia. In Prosiding Seminar Serantau, 8, 382-390).

Abdul Hameed, A. M. (2015). Blended Scaffolding Strategies through Facebook for Learning and Improving the Writing Process and Writing Performance. Journal of Social Sciences and Humanities, 255-279.

Al Mubarak, A. A. (2016). Learning English as a second language through social media: Saudi Arabian tertiary context. International Journal of Linguistics, 8(6), 112-127.

Alm, A. (2006). CALL for autonomy, competence and relatedness: Motivating language learning environments in Web 2.0. The JALT CALL Journal, 2(3), 29-38).

Che Wan Ida Rahimah Bt Che Wan Ibrahim. (2018). Social Media Tools forInformal Language Learning: A Comprehensive Theoretical Framework. Asian Social Science, 14, 46-50.

Tartari, E. (2015). The use of social media for academic purposes in student'learning process. Academic Journal of Interdisciplinary Studies, 4(2), 393-398.

Ghani, A. M. B. (2015). Using Facebook in Teaching and Learning English. 97-101.

Henriksen, D., Mishra, P., \& Mehta, R. (2015). Novel, effective, whole: Toward a NEW framework for evaluations of creative products. Journal of Technology and Teacher Education, 23(3), 455478.

Madge, C., Meek, J., Wellens, J., \& Hooley, T. (2009). Facebook, social integration and informal learning at university: 'It is more for socialising and talking to friends about work than for actually doing work'. Learning, media and technology, 34(2), 141-155.

Yunus, M. M., Salehi, H., \& Chenzi, C. (2012). Integrating social networking tools into ESL writing classroom: Strengths and weaknesses. English language teaching, 5(8), 42-48.

Mohammad, M., Ghazali, N., \& Hashim, H. (2018). Secondary School Students' Perceptions on the Use of Google+ towards Improving ESL Writing Skills. International Journal of Emerging Technologies in Learning, 13(9).

Mansor, N. (2016). Enhancing communication via social media in ESL classroom. In 6th International Conference on Language, Education, and Innovation, 52, 140-146.

Kasuma, S. A. A. (2017). Using Facebook for English Language Learning: the differences among gender and ethnicity. Journal of Nusantara Studies (JONUS), 2(1), 177-193.

Yunus, M. M. (2018). Innovation in education and language learning in 21st century. Journal of Sustainable Development Education and Research, 2(1), 33-34.

Kabilan, M. K., Ahmad, N., \& Abidin, M. J. Z. (2010). Facebook: An online environment for learning of English in institutions of higher education?. The Internet and higher education, 13(4), 179187. 